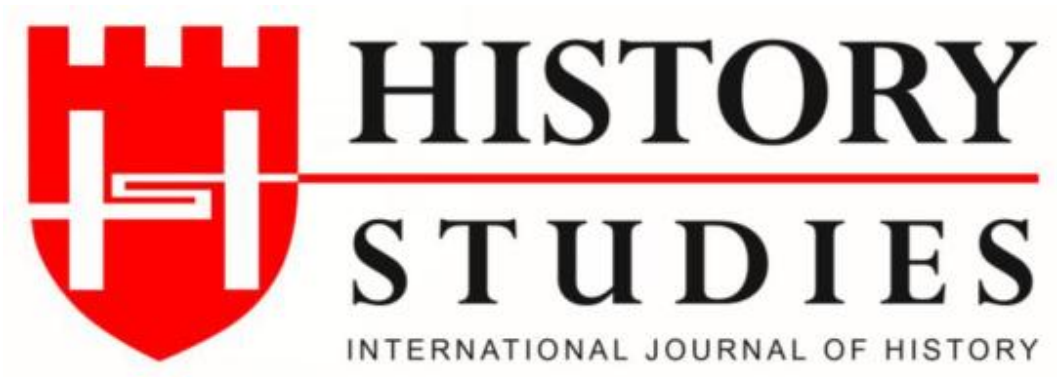

ISSN: 13094173 (Online) 1309 - 4688 (Print)

Volume 10 Issue 9, p. 55-84, December 2018

DOI Number: 10.9737/hist.2018.675

\title{
The Beginning of a New Era in the Cyprus Problem after the 1967 Crisis: The Inter-Communal Talks"
}

\author{
1967 Krizinden Sonra Kıbrıs Sorununda Yeni Bir Dönemin Başlangıcı: \\ Toplumlararası Görüşmeler
}

\author{
Dr. Yasin COȘKUN \\ (ORCID: 0000-0002-8151-7874) \\ Siirt Üniversitesi - Siirt
}

\begin{abstract}
Öz: Bu çalışma 1967 yllının Kasım ayında Kıbrıs'ta yaşanan ve Türkiye ile Yunanistan'ı savaşın eşiğine getiren krizin sonrasından başlayarak 1971 yılına kadar olan dönemde Kıbrıs sorunundaki gelişmeleri ele almaktadır. Bu çerçevede ilk olarak 1967 yllının Aralık ayındaki Kıbrıs Geçici Türk Yönetimi'nin ilanı ve bu ilana gösterilen tepkiler analiz edilmiştir. 1967 Kasım krizinin bir kez daha adadaki Türklerin korumasız olduğunu gösterdiğini savunan Kıbrıslı Türkler, kurulan bu yeni yönetimin adadaki Türkler için bir güvence olduğunu ifade etmişlerdir. 1968 yılı itibariyle Kıbrıs sorununa çözüm bulabilmek için adadaki iki toplum arasında görüşmeler başlamıştır. Bu açıdan bu tarih Kıbrıs sorunu açısından önemlidir. Daha önceleri Ankara ve Atina arasında yürütülen görüşmeler artık Kıbrıslı Türkler ve Rumlar arasında yürütülmeye başlanmıştır. Bu çalışma iki toplum arasındaki bu görüşmeleri mercek altına almıştır. Türk tarafi bu görüşmelerde zaylf bir merkezi yönetim ile beraber yerel özerkliğin artmasını isterken Rum tarafi ise güçlü bir merkezi devlet yapısının oluşturulmasını savunmuştur. İki taraf arasındaki bu anlaşmazlık görüşmelerin 1971 yılında kesilmesiyle sonuçlanmıştır. Bu tarihlerde EOKA terör örgütünün kurucusu Grivas'ın adaya gizlice dönerek EOKA-B adı altında yeni bir örgüt kurduğu ortaya çımıştır. Bu durum Kıbrıs sorununun geleceğine dair adadaki endişeleri arttırmıştır. Tüm bu konu başlıkları çalışmada ele alınmıştır.
\end{abstract}

Anahtar Kelimeler: Kıbrıs Sorunu, Rauf Denktaş, Glafkos Kliridis, Toplumlararası Görüşmeler

\begin{abstract}
This study examines the developments in the Cyprus problem starting from the post-1967 crisis to 1971. Firstly, the declaration of the Turkish Cypriot Provisional Administration in December 1967 and the reactions to this declaration were analysed. The Turkish Cypriots, who argued that the November 1967 crisis once again proved that the Turks on the island were unprotected, stated that this new administration was a guarantee for the Turks on the island. In 1968, negotiations between the two communities on the island began in order to find a solution to the Cyprus problem. In this respect, this date is important for the Cyprus problem. Previously, negotiations were made between Ankara and Athens, but after 1968, negotiations were carried out between the Greek and Turkish Cypriots. This study has examined these negotiations between the two communities. While the Turkish side wanted to increase local autonomy with a weak central government, the Greek side advocated the formation of a strong central state structure. Because of the disagreement between the two sides the negotiations were interrupted in 1971. At that time, it was revealed that the founder of the EOKA terrorist organization, Grivas, secretly returned to the island and established a new organization under the name of EOKA-B. This situation increased the concerns about the future of the Cyprus problem. All these topics are examined in this study.
\end{abstract}

Keywords: The Cyprus Problem, Rauf Denktaş (Denktash), Glafcos Clerides, the Inter-communal Talks

* This article is based on a chapter from the author's PhD thesis: Yasin Coşkun, "The Cyprus Problem and AngloTurkish Relations 1967-1980” (unpublished PhD Thesis, University of East Anglia, 2015). 


\section{Introduction}

This article examines the developments in the Cyprus issue from December 1967 until the suspension of the inter-communal talks in 1971 and evaluates British and Turkish policy in this time period. The first section investigates the Turkish Cypriot move to set up their own administration on the island and the arguments they used to justify their action. Also, the international reaction towards the Turkish move is analysed in this section. In particular, the British opinion on the idea of a separate Turkish administration on the island is examined, raising the question as to whether the Turkish move actually had British support or whether Britain was against it.

The second part of this article demonstrates the situation in Cyprus and British policy by 1968. There was no major crisis on the Cyprus problem from this date to 1974. The negotiations took place between the Greeks and Turks for a settlement. The events that happened in this time period did not significantly affect Anglo-Turkish relations. The British government's assessments of the Turkish policy within this negotiation process provide information which allow to examine both sides view on possible solutions to the Cyprus problem.

After the failure of the attempts by Athens and Ankara to solve the problem, the direct talks began between the local Greek and Turkish Cypriot leaders, Clerides and Denktash, which was an important step in finding a permanent solution to the Cyprus issue. However, the talks were not productive and each side revealed attitudes which caused prolonging the ongoing problems. Therefore, apart from evaluating the approaches by both sides, the third part of this article looks at the British assessment on these unproductive talks. This gives an idea about how the Turkish attitude in the talks was regarded by Britain. In this context, the reports by British High Commissioner on the ongoing talks between the two communities on the island were used as the primary sources. Furthermore, the British and Turkish fear of Soviet involvement in the Cyprus question is also investigated.

The final part of this article looks at the suspension of the talks between the two communities in 1971 and the establishment of "EOKA-B", a terrorist organisation established by the Greek leader Grivas, are also examined. The establishment of "EOKA-B" caused fear that inter-communal clashes were going to start again on the island. Therefore, the developments after the suspension of the negotiation process, which produced only deadlock, are investigated in this section.

1. The Establishment of the "Turkish Cypriot Provisional Administration" and British Reaction

In the 1950s, Cyprus was under British rule. However, the Turkish Cypriots were concerned about the activities of the Greek Cypriots for enosis ${ }^{1}$ (union of Cyprus with Greece). Clashes began between the two communities on the island. After the establishment of the Republic of Cyprus in 1960, there was a relatively peaceful environment on the island. However, after the constitutional crisis at the end of 1963, inter-communal fighting started again. Turkey thought that the position of the Turks in Cyprus was unprotected. Thereupon, the Turkish Security Council (NSC) took a decision to intervene on the island, but on 5 June 1964, the US President Lyndon Johnson's threatening letter reached Turkey which prevented

${ }^{1}$ Resul Babaoğlu, “Türkiye'nin Kıbrıs Politikasının Evriminde Bir Dönüm Noktası: Londra Konferansı (29 Ağustos-6 Eylül 1955)”, Çağdaş Türkiye Tarihi Araştırmaları Dergisi, Cilt: 18, Sayı:36, Bahar-2018, p. 326. 
Turkish military action in Cyprus. On the other hand, the letter adversely affected AmericanTurkish relations. On November 1967 the Greeks attacked two Turkish villages in Cyprus. This November crisis was an important event on the island; Turkey was about to launch a military operation to protect the Turkish Cypriots but this was halted by American intervention.

After the Cyprus Crisis of 1967 the situation on the island was still fragile and it seemed that any small confrontation between the two communities could possibly turn into a major crisis again. It appeared that the 1967 crisis had an adverse effect on the hope that the Greek and Turkish Cypriots could find a possible way to unite and live under one flag like happened in 1960. Actually, at first, the 1964 Cyprus crisis had played an important role in this separation process but the November crisis in 1967 accelerated it.

From the Turkish point of view, the establishment of a separate Turkish administration on the island was necessary and unavoidable. The Turks demonstrated some reasons to justify their action. Firstly, they argued that, after the December 1963 crisis, the Turkish Cypriots were obliged to live in a very difficult condition both economically and socially. Moreover, they were not allowed to take part in the Cyprus government. ${ }^{2}$ Therefore, this situation on the island was a significant factor in making the rift wider between the two communities and leading the Turkish Cypriots to form their own administration. Secondly, there was a general Turkish opinion that the 1967 crisis one more time demonstrated that the Turkish Cypriots were unprotected and were significantly damaged by the event. As a result of this, establishing a separate government would provide better protection for the Turkish community on the island. Thirdly, the Turks wanted to unite all of the different Turkish Cypriots groups and gather them under the one administration. ${ }^{3}$ The main motivations for this action were to prevent any conflict between these groups and make the Turkish position stronger. ${ }^{4}$ Overall, these were the general Turkish arguments to demonstrate the necessity of the new Turkish Cypriot Administration. However, the other actors in the Cyprus problem would not consent to this Turkish action of establishing a separate Turkish administration and would not show any support for it.

The Turks were not fully happy with the result of the 1967 crisis. However, when compared to the Greek side, it seemed that the Turks gained more advantages from the agreement between Greece and Turkey. Moreover, the Greek public opinion felt that Greece accepted "humiliating conditions imposed by Turkey following the November 1967 Ayios Theodhoros (Boğaziçi) and Kophinou (Geçitkale) clashes in Cyprus". ${ }^{5}$ Therefore, Turkish Cypriots decided that this atmosphere was the right time to set up their own management ${ }^{6}$ and they declared the establishment of "Turkish Cypriot Provisional Administration" on 28 December $1967 .^{7}$

\footnotetext{
${ }^{2}$ Rauf Denktash, The Cyprus Triangle, K. Rustem \& Bro, Nicosia 1982, p. 34-35.

${ }^{3}$ Ercüment Yavuzalp, Kıbrıs Yangınında Büyükelçilik, Bilgi Yayınevi, Ankara 1993, p. 116-125.

${ }^{4}$ Ibid.

${ }^{5}$ Marios L. Evriviades, "Greek Policy and Cyprus: An Interpretation”, Journal of the Hellenic Diaspora, Vol. 14, No. 3-4, (Fall 1987), p. 38.

${ }^{6}$ Melek Fırat, Yunanistan'la İlişkiler”, Türk Dış Politikası Kurtuluş Savaşından Bugüne Olgular, Belgeler, Yorumlar 1919-1980, Ed. Baskın Oran, C. I, İletişim Yayınları, İstanbul, 2010, p. 738.

${ }^{7}$ Metin Tamkoç, The Turkish Cypriot State :The Embodiment of the Right of Self-determination, K. Rustem \& Brother, London 1988, p. 116., Yavuz Güler, "Kuzey Kıbrıs Türk Cumhuriyeti'nin Kuruluşuna kadar Kıbrıs Meselesi”, G.Ü. Kırşehir Ĕ̈itim Fakültesi Dergisi, Vol. 5, No. 1, 2004, p. 108.
} 
Actually, since 1964, there had been a separate Turkish administration which had been called a "general Committee" ${ }^{8}$ but it was not fully organised. On the other hand, "the newly established administrative machinery was to a certain extent a formalization and extension of the ad hoc administration which had existed in the Turkish areas of Cyprus"9 since 1964. It "had total control over the Turkish enclaves covering 250 of the 9,251 square kilometres of the island's territory. The major Turkish Cypriot enclave was to the north of Nicosia and accounted for 40,000 Turks, or one-third of the Turkish population." ${ }^{\prime 10}$ Dr. Küçük was chosen President, and Denktash, Vice-President of this administration ${ }^{11}$, although he was living in exile at that time.

The Turkish side knew that there would be some reaction to their action. Thus, they wanted to be cautious to minimise the international criticism. By putting the phrase of the "provisional" in front of the name of the new administration, the Turks tried to express the point that this was not a step towards partition of the island ${ }^{12}$ and it was announced that the Provisional Administration would operate until the provisions of the 1960 constitution were applied. ${ }^{13}$ Despite all of these Turkish efforts, there were strong reaction to the new formation. In particular, the Greek side showed a harsh response. Makarios and Athens protested ${ }^{14}$ against the Turkish action and the Greek Cypriot government declared that the new Turkish Administration was unlawful and illegal on 29 December $1967 .{ }^{15}$ The Greek Cypriot Foreign Minister, Kyprianou, "also issued notes on 28 December 1967 to all embassies in Nicosia forbidding their ambassadors to have any contact with the Turkish Cypriot leadership". ${ }^{16}$ The Greek side seemed to be surprised and frustrated. The basic law of this new Turkish administration also was an important factor in the Greek anxiety. It consisted of 19 provisions which authorized the new Administration to use the legislative, executive and juridical power in the Turkish areas on the island. ${ }^{17}$ Athens also stated that the Turkish action was a partition attempt which "creates a very serious situation." ${ }^{18}$ According to Athens' opinion, "Greece and Turkey had agreed to settle the November crisis to disarm and create a better climate in which a permanent solution of the Cyprus problem would be possible. By their action the Turks evidently want to prejudice such a solution and impose their own."19

After the Greek reaction, the Turkish Foreign Minister Çağlayangil made a statement and underlined the point that this new and provisional formation just aimed to give an end to disorder in the Turkish Cypriots affairs and organise the community to help to find a solution to the Cyprus problem. He also stressed that this action should not be interpreted as a Turkish

\footnotetext{
${ }^{8}$ Cihat Göktepe, “The Cyprus Crisis of 1967 and its Effects on Turkey's Foreign Relations”, Middle Eastern Studies, 41: 3, 2005, p. 441., Zaim M. Nedjatigil, The Cyprus Conflict A Lawyer's View, Tezel, 2nd edn, Nicosia 1982, p.39., Fırat, "Yunanistan'la İlişkiler", p. 738.

${ }^{9}$ Sharon Anderholm Wiener, Turkish Foreign Policy Decision-Making on the Cyprus Issue: A Comparative Analysis of Three Crises, (Ph.D. Thesis), Duke University 1980, p. 223.

${ }^{10}$ Süha Bölükbaş1, “The Cyprus Dispute and the United Nations: Peaceful Non-Settlement between 1954 and 1996 International Journal of Middle East Studies, Vol. 30, No. 3, August, 1998, p. 420.

${ }^{11}$ Aydın Olgun, Dünden Bugüne Kıbrıs Sorunu, Kastaş Yayınları, İstanbul 1999, p. 20., Göktepe, "The Cyprus Crisis of 1967”, p. 441., Milliyet, 30 December, 1967., The Times, 30 December 1967.

${ }^{12}$ Yazuzalp, Kıbrıs Yangınında Büyükelçilik, p. 123.

${ }^{13}$ Nedjatigil, The Cyprus Conflict, p. 39., Wiener, Turkish Foreign Policy, p. 223.

${ }^{14}$ Milliyet, 31 December, 1967.

${ }^{15}$ Yazuzalp, Kıbrıs Yangınında Büyükelçilik, p. 127.

${ }^{16}$ Parker T.Hart, Two NATO Allies at the Threshold of War: Cyprus, a Firsthand Account of Crisis Management, 1965-1968, Duke University Press, London 1990, p. 114.

${ }^{17}$ Denktash, The Cyprus Triangle, p. 35., Nedjatigil, The Cyprus Conflict, p.39., Vatan, 29 December 1967.

${ }_{18}^{18}$ Dışişleri Bakanlığı Belleteni, no: 39, December 1967, p. 87.

${ }^{19}$ The Times, 30 December 1967.
} 
divergence from the pursuit of a peaceful solution to the Cyprus issue. ${ }^{20}$ However, this explanation from the Turkish side was not enough to gain support for their action. Apart from the Greeks, Britain was also discontented with the new Turkish Cypriot Administration on the island. "First reaction in Whitehall was that the Turkish Cypriot move was an "unwelcome development". ${ }^{21}$ The Foreign and Commonwealth Office's Research Department's assessment also showed the British attitude towards the Turkish action:

"Unfortunately, (after the 1967 crisis) the first political move by the TurkishCypriot community (and by Ankara) was a move backwards, by setting up a TurkishCypriot Provisional Administration in December 1967. The Turkish government denied that this meant the establishment of a separate government or Republic, but the Turkish-Cypriot's action produced serious objection from Archbishop Makarios, and his banning of official contacts between Head of Mission and Dr. Fazıl Küçük and his administration caused the Turkish and allied governments to make a great deal of diplomatic effort before the matter was resolved. $" 22$

In a discussion in the British Cabinet, it was also stated that "the situation in Cyprus had recently become more critical as a result of the decision of the Turkish Cypriot community to set up their own separate administration." ${ }^{, 23}$ The U.S. also seemed to be surprised by the Turkish move. According to the U.S. ambassador to Turkey Parker T. Hart, "the articles of the basic law of the new Administration resembled a constitution and the move appeared to presage formation of a separate state and diminish the chances of reconciliation and unity."24 $\mathrm{He}$ also protested vigorously about the notion of a "Provisional Turkish Cypriot Administration" when he met the Turkish Foreign Minister İhsan Sabri Çağlayangil in Ankara. ${ }^{25}$

The Turkish side again made an explanation and emphasized that "its purpose was not to create a Turkish Cypriot government, but to pull together discordant factions of the community who were at serious crossed purposes and to strengthen leadership in preparation for tough negotiations with the Greek Cypriot community toward pacification and inter-communal political cooperation." ${ }^{26}$ Actually, the reactions to the Turkish move left Turkey in a difficult situation. Therefore, Ankara sent a note to the Turkish Embassy in Nicosia and complained that the declaration of the new Administration should have been made silently. ${ }^{27}$ The broad statement attracted attention to the island and increased the international pressure on the Turkish government. In his report to the Security Council on the establishment of the Turkish administration on the island on 4 January, the UN Secretary-General, U Thant, also criticised the Turkish action and said "this move could damage my friendly initiative in the Cyprus problem. ${ }^{, 28}$ As a reply to U Thant, the Turkish Ministry of Foreign Affairs stated that they did not share the same concern as him. ${ }^{29}$ The Vice-President of Cyprus, Dr. Küçük, also sent a letter to $\mathrm{U}$ Thant on 10 January in which he mentioned the difficult situation of the Turkish community on the island and tried to explain the necessity of such a move from the Turkish

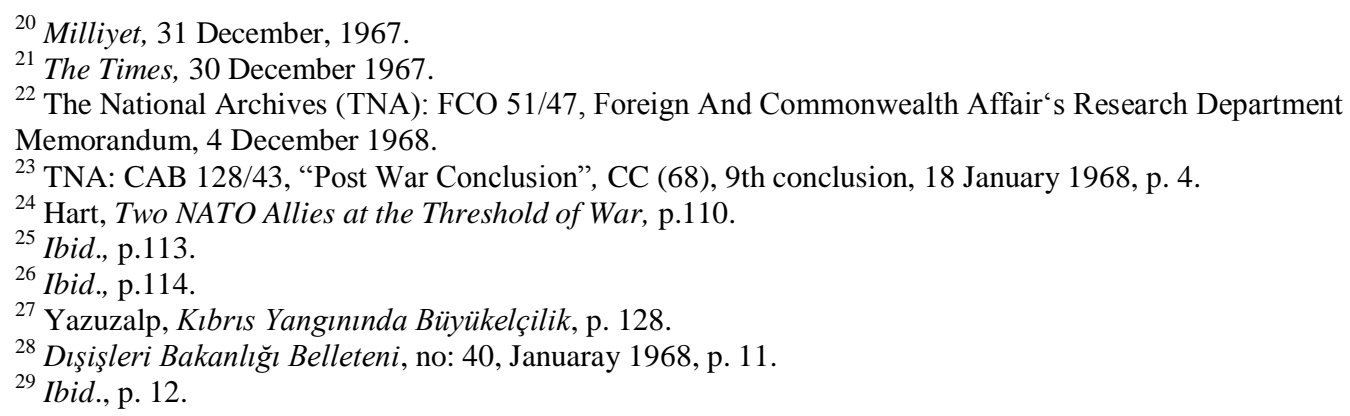


Cypriots. ${ }^{30}$ Meanwhile, the Greek Cypriot leader Makarios increased the amount of opposition to the new Turkish Administration. He "prevented any official or member of the Turkish Cypriot administration from entering or leaving the Turkish quarter of Nicosia"31. He later announced that his intention was "to restrain the activities of an unlawful administration which are calculated to undermine the unity of the "state." 32

Britain also closely monitored the developments by getting information from the British High Commission on the island. According to this information:

"The restriction by Makarios covers all members of both committee of the new Administration: this means the eleven members of the Executive Committee and all Turkish Cypriot members of the House of Representatives and of the Turkish Communal Chamber. In addition, the Under-Secretary to the Vice-President, who has no connection with the T.C.P.A. (Turkish Cypriot Provisional Administration), is restricted. In explaining the inclusion of the Under-Secretary, the Greek Cypriot official said that, since Küçük was not Vice-President and had no public office except in the T.C.P.A., the Under-Secretary presumably served him in that capacity and must therefore be restricted!" 33

The Turkish Cypriot judges were excluded from the restriction by the Makarios government. However, as stated in the British High Commission, "this is interpreted to mean that, if the Turkish Cypriots give effect to Articles 16-18 of the basic provision of the T.C.P.A. the judges will be restricted." ${ }^{34}$ In particular, Article 17 was allowing the new Turkish Administration to set up separate courts. ${ }^{35}$ Therefore, the Greek side wanted to prevent application of these Articles. According to the British assessment about the situation on the island, it was indicated that:

"We have no indication that the Turkish Cypriots intend to implement Articles 1618 of the Basic Provisions shortly. Even if they do, as long as they act discreetly, carrying on the same sort of courts set-up that they have operated since 1964, it is unlikely to give rise to trouble. But ostentatious implementation of Articles 16-18 would probably provoke a sharp reaction from the "Cyprus government" including the restriction of the judges to the Nicosia enclave." 36

On the other hand, the restriction from the Greek side increased the frustrations among the Turkish Cypriots on the island which could trigger another inter-communal conflict between the both sides. As reported by British officials:

"If the restriction were to be thus extended the Turkish Cypriots, who are already making an issue of the restriction, would in turn react badly. They are currently taking the line that "all illegal restrictions must be removed if any real progress is to be made towards a settlement." This line is reflected in the Turkish Cypriot publications such as their daily news bulletin. ",37

${ }^{30}$ Ibid., p. 40-41.

${ }^{31}$ The Times, 5 January 1968.

${ }^{32}$ Ibid.

${ }^{33}$ TNA: FCO 9/85, “United Nations Peacekeeping Force in Cyprus (UNFICYP): finances and support”, 'Cyprus', letter from the British High Commission in Cyprus, 2 February 1968.

${ }^{34}$ Ibid.

${ }^{35}$ Vatan, 29 December 1967

${ }^{36}$ TNA: FCO 9/85, op. cit.

${ }^{37}$ Ibid. 
Makarios also seemed to understand the seriousness of the situation. Thus, it was announced that, except for the member of the T.C.P.A., "full freedom of movement would be restored throughout the island for all other members of the Turkish Cypriot community by the abolition of all check-points and the lifting of all existing restrictions on the supply of various good." 38 However, according to the British High Commission's assessment, "If and when Archbishop Makarios honours his undertaking to lift the economic restrictions on Nicosia after the Presidential election, the Turkish Cypriots will doubtlessly say that it does not really alter the situation since restriction on T.C.P.A. members is maintained." 39

The Greek reaction to the Turkish Administration started to decrease in time. Their call for forbidding any contact with the Turkish Cypriot leadership did not get support from the Embassies in Nicosia. ${ }^{40}$ This call was also "protested vigorously by the United States and other governments as unrealistic and extreme. Consequently, Washington decided to refuse the Greek Cypriots' position". ${ }^{41}$ As a result of this, the Greek Cypriots withdrew their opposition to the contact with the Turkish Cypriot Leadership in Nicosia. ${ }^{42}$ After examining the Turkish decision to set up their own administration in Cyprus and the reactions towards this decision, the next section analysed the Cyprus problem by 1968 and the British approach to developments in the problem.

\section{The Situation in Cyprus by 1968 and British Policy}

In terms of the Cyprus problem, there were important events in the year of 1967 which drew international attention to the island. First, the Czechoslovak Arm dispute, then, the meeting of the Turkish and Greek Prime Ministers, later, the November Crisis and finally, the establishment of "Provisional Turkish Cypriot Administration" on 28 December 1967. Nevertheless, there was no solution for the problem and the Cyprus dispute was still unresolved at the beginning of 1968. As a result of this, the danger of any future conflicts between the two communities continued to remain a serious concern.

When compared to the last three months of the previous year, there was very little tension on the island by 1968. Although the Greek Cypriots still called the Turkish Cypriots move illegal, they adapted themselves to the new situation in Cyprus. The first important event on the island in 1968 was the Presidential election which Makarios announced would be held in Cyprus on 25 February. ${ }^{43}$ The Turkish Cypriot leadership felt uneasy with the decision of Makarios. According to the Article 39 of the 1960 constitution, the Presidential and VicePresidential election needed to be held on the same day. However, Makarios called the Turkish Cypriots leadership "rebels" and did not consult with them while deciding the election day. ${ }^{44}$ As a result of this, the Turkish side planned to make a surprise move and the Turkish Cypriot leader Dr. Küçük announced that "there would be a Turkish election for Vice-President of the Republic on February 25, the same day as Greek Cypriots have been warned to be ready for polls to elect a President." ${ }^{45}$ In addition, "Dr. Küçük said that the decision had been taken in accordance with the provisions of the 1960 constitution which stipulates that Greek Cypriots shall elect a President of the Republic and Turkish Cypriots a Vice-President." ${ }^{\text {"46 }}$ The Turks

\footnotetext{
${ }^{38}$ The Times, 5 January 1968.

${ }^{39}$ TNA: FCO 9/85, op. cit.

${ }^{40}$ Yazuzalp, Kıbrıs Yangınında Büyükelçilik, p. 130.

${ }^{41}$ Hart, Two NATO Allies at the Threshold of War, p. 114.

${ }^{42}$ TNA: FCO 9/73, "Cyprus", report of the Central Department of Foreign Office, 20 March 1968.

${ }^{43}$ The Times, 13 January 1968.

${ }^{44}$ Yazuzalp, Kıbrıs Yangınında Büyükelçilik, p. 133.

${ }^{45}$ Dışişleri Bakanlı̆̆ Belleteni, no: 40, Januaray 1968, p. 5., The Times, 22 January 1968.

${ }^{46}$ Ibid.
} 
thought that if they did not call for the election this would strengthen the Greek Cypriots' hand to not recognise the status of a Turkish Cypriot Vice-President. ${ }^{47}$ However, from the Greek Cypriots' perspective, "the Turkish decision was considered to be without a legal basis and the proposed election "could not have any validity." crisis. The trigger was usually a relatively trivial or mundane event which was then interpreted as an issue of status or prestige.

Apart from the Greek Cypriot opposition, another problem for the Turkish side was the choice of the candidate for the Vice-Presidential election. A former Chief Justice of Cyprus, Mehmet Zeka Bey, was being shown among the possible candidate on the island. ${ }^{49} \mathrm{He}$ had good relations with the Greek side and his candidacy was also supported by the Greek Cypriots. ${ }^{50}$ However, Turkey wanted Dr. Küçük to be the Vice-President and was opposed to anyone other than him because, according to the Turkish government's view, two candidates for the Vice-President position could harm the unity of the Turkish Cypriot community. ${ }^{51}$ Thus, the Turkish ambassador to Cyprus, Yavuzalp had a meeting with Zeka Bey and explained to him the position of Turkey. Zeka Bey decided not to be a candidate in the election. It was most likely that the most important factor in his this decision was that he did not want to have problem with Turkey. After the elimination of the possible applicants for the position of the Vice-Presidency, the Turkish side did not see any necessity to wait for 25 February and went to the poll before that day on 15 February and Dr. Küçük was chosen as the Vice-President once again. ${ }^{52}$

Meanwhile, the Greek Cypriots were preparing for the upcoming Presidential election. From Makarios' perspective, this event was vital. He stated that "after the failure of the GrecoTurkish dialogue and withdrawal of the Greek military forces, the Cyprus problem had entered a critical stage. ${ }^{, 53} \mathrm{He}$ seemed to understand that his role in finding a solution to the problem would increase because the military regime in Athens, by beginning to withdraw their troops after the November 1967 crisis, "had lost much, but not all, of their influence over the Archbishop Makarios, leaving him more freedom" 54 to pursue his own policies. For this reason, the election on 25 February was a significant opportunity to reaffirm his power with the Greek Cypriots which would strengthen his hand to take more initiative and act more independently in the Cyprus issue. The result of the election was satisfactory for Makarios. He "received an exceptionally strong mandate by winning 95 percent of the votes against Dr. Evdokas, who had campaigned on a platform based on Enosis". ${ }^{55}$ After the election, as he declared before, Makarios started to apply the pacification policy on the island. In this context, he "lifted restriction on the Turkish Cypriot community on 7 March 1968 and removed the

\footnotetext{
${ }^{47}$ Yazuzalp, op. cit., p. 133-34.

${ }^{48}$ The Times, 22 January 1968.

${ }^{49}$ Ibid.

${ }^{50}$ Yazuzalp, op. cit., p. 138.

${ }^{51}$ Richard A. Patrick, Political Geography and the Cyprus Conflict 1963-1971, Department of Geography, Faculty

of Environmental Studies, University of Waterloo, Canada 1976, p. 157.

${ }_{52}$ Ibid., 142-43., Dışişleri Bakanlı̆̆ Belleteni, no: 41, February 1968, p. 5.

${ }^{53}$ Polyvios G. Polyviou, Cyprus in Search of a Constitution, Nicolaou, Nicosia 1976, p. 73., Nedjatigil, The Cyprus Conflict- a Lawyer's View, p. 40.

${ }^{54}$ TNA: FCO 51/47, Foreign And Commonwealth Affair‘s Research Department Memorandum, 4 December 1968.

${ }^{55}$ Tozun Bahcheli, Greek-Turkish Relations since 1955, Westview Press, London 1990, p. 75., Michael M. Carver, The Gordian Knot: American And British Policy Concerning The Cyprus Issue: 1952-1974, (M.A. Thesis), Bowling Green State University 2006, p. 76.
} 
barricades and roadblocks surrounding the Turkish areas. ${ }^{, 56}$ This move was considered to be a significant step towards a "normalisation" process on the island. Britain also seemed to be happy with the developments. The British assessment on 20 March 1968 showed the situation in Cyprus:

"During the past three months Cyprus has been quieter than for a long time. The Cyprus government have been progressively lifting the restrictions which they had imposed on the Turkish Cypriots. The process recently culminated in the removal of roadblocks and checkpoints in Nicosia itself. This will make life considerably easier for the Turkish Cypriots. Their public reaction has been rather reserved so far, but what the Turkish Representative said during the debate in the Security Council suggests that these "normalisation" measures will improve the atmosphere considerably if no unfortunate incidents occur to raise tension again. "57

Despite all of these, there were still some problems. The UN urged the Turkish Cypriot Leadership to respond to the Greek's move by opening the Turkish enclaves to Greek Cypriot travel but the Turkish side expressed their unwillingness to do so. ${ }^{58}$ Similarly, Britain shared the same idea with the UN. The British Foreign Secretary tried to urge the Turkish Foreign Minister, Çağlayangil, to respond to the Greek Cypriots' pacification measures, which were welcomed by the British government. ${ }^{59}$ However, the British ambassador to Turkey, Sir Roger Allen, indicated that the Turks considered "normalisation" "as no more than palliative." ${ }^{60}$ As a result of this, he said, the Turks would not be likely to regard the notion that "normalisation would lead to a deal between themselves and Makarios." ${ }^{\prime 1}$ This situation caused a Greek reaction and another discussion arose after the beginning of the "normalisation" process. In a meeting with the British Commonwealth Secretary, the Greek Cypriot side complained about "the strict control maintained by Turkish leadership" in Turkish enclaves. ${ }^{62}$ They also stated that "the Turks must realise that the restrictions that they were maintaining were not a bargaining factor on their side; the real harm was only to themselves." ${ }^{\prime 63}$ The Greek Foreign Minister, Pipinellis, also stated that the Turkish Cypriots needed to respond to Makarios' "normalisation" measures. ${ }^{64}$

However, the Turkish Cypriots defended their position by explaining that "Turkish Cypriots who travelled on the roads would, in any case, have to submit to the Greek Cypriot police and military control." ${ }^{65}$ Therefore, the same procedure would be applied to the Greek Cypriots when entering the Turkish Cypriot areas. While the discussion about the "normalisation" process continued, both sides seemed to be eager to make a fresh move for the solution of the problem. The UN was working assiduously to find a peaceful settlement for the Cyprus dispute. Hence, UN Secretary-General U Thant tried to arrange a contact between the

\footnotetext{
${ }^{56}$ Hart, Two NATO Allies at the Threshold of War, p. 117., Theodore A. Couloumbis, The United States, Greece and Turkey: The Troubled Triangle, Praeger, New York 1983, p. 76., Nasuh Uslu, The Cyprus Question as an Issue of Turkish Foreign Policy and Turkish-American Relations 1959-2003, Nova Publishers, New York 2003, p. 109.

${ }^{57}$ TNA: FCO 9/73, "Cyprus", report of the Central Department of Foreign Office, 20 March 1968.

${ }^{58}$ Hart, op. cit., p. 117.

59 TNA: FCO 9/73, "Cyprus", record of conversation between the Commonwealth Secretary and the Cyprus Foreign Minister held at Admiralty House, 28 June 1968.

${ }^{60}$ TNA: FCO 9/72, "Cyprus", telegram from the British Ambassador to Turkey, Sir. Roger Allen, to Foreign Office, 18 October 1967.

${ }^{61}$ TNA: FCO 9/73, op. cit.

${ }^{62}$ Ibid.

${ }^{63}$ Ibid.

${ }^{64}$ Dışişleri Bakanlığ Belleteni, no: 43, April 1968, pp. 29-30.

${ }^{65}$ Denktash, The Cyprus Triangle, p. 53.
} 
Greek Cypriot and Turkish Cypriot Representative under the United Nations chairmanship. ${ }^{66}$ According to the British, "the Turkish government was not objecting and it seemed likely that such talks would start soon."67

Actually, the situation on the island was conducive to starting a talk between the two communities. After the election and the withdrawal of the Greek forces from the island, Makarios gained more political power. Turkey was also ready to accept the negotiations between the Greek and Turkish Cypriots. As a result of this, Britain became positive about the future of the Cyprus issue, although there were still some concerns. According to the British evaluation:

"The prospects of progress towards a new settlement in Cyprus are now rather better than they have been for some time, and much better than would have seemed at the time of the crisis last November. But it will be a long haul and the situation is still potentially dangerous. We do not think that the Cyprus government fully realised how perilous their situation was last November. They may well be over-confident about their ability to outmanoeuvre the Turks and to avoid further threat of a Turkish invasion. In Turkey, on the other hand, there is a widespread feeling that if would have been much better if Turkey had invaded Cyprus last year and settled the matter. Given all this, and the fact that the position of Turkish and Cypriot governments are still very far apart as regards the lines of the future settlement, there is a clearly a risk that if the discussion now proposed end in deadlock and if there is a recurrence of serious incidents on the island we will once again have a very tense situation in the Eastern Mediterranean. And we shall have to do our best to see that the discussion do not end in deadlock. But there is no immediate requirement for intervention by H.M.G in pursuance of our present policy over the dispute. "68

After these important developments on the island, Britain wanted to review its policy over the Cyprus issue. As a result of this, in a meeting in the Commonwealth Office at the end of January, the British Head of Missions from Nicosia, Ankara and Athens discussed the Cyprus policy and outcome of this meeting was also approved by the Foreign Secretary and the Commonwealth Secretary. According to this, Britain decided that:

"In close consultation with our allies, especially the United State and Canada, we should:

a) Plan on the basis of an independent Cyprus in the Commonwealth for the foreseeable future;

b) Do everything in our power to keep Cyprus westward-looking and prevent the Soviet Union from increasing its influence on the island;

c) Support the efforts of the U.N. Secretary-General.

d) Exert our influence on Archbishop Makarios to persuade him to adopt a conciliatory policy towards the Turkish Cypriots;

e) encourage the Turkish government to allow the Turkish Cypriots to make a positive response to any conciliatory moves made by the Greek Cypriots; and in the

${ }^{66}$ TNA: FCO 9/73, report of the Central Department of the Foreign Office, 20 March 1968.

${ }^{67}$ Ibid.

${ }^{68}$ Ibid. 
long term once adequate constitutional arrangements have been made for the Turkish Cypriots, to disengage themselves from the internal affair of Cyprus;

f) Encourage the Greek government in the short term to continue the realistic policy which they adopted in November and in the long term to give up Enosis altogether;

e) Ensure that no agreement contains any provision that might adversely affect the position of the Sovereign Base Areas and our related rights in Cyprus while we still need them. "69

Britain understood that the dialogue, which was going to start soon, between the Greek and Turkish Cypriots communities, would have a significant role in solving the problem. Therefore, Britain was in favour of supporting and encouraging such an initiative while giving importance to protecting and maintaining its rights on the island.

\section{The Beginning of the Inter-Communal Talks}

After becoming a stage for years of struggles between the two communities, Cyprus seemed to be ready to start a fresh beginning. The inter-communal talks were a significant measure of the Cyprus question and were ambitious efforts which also gained the international support. From this angle, an analysis of this process has a vital importance while investigating the Cyprus issue. Certainly, it was not easy to attempt to bring the two communities to the negotiating table. The first matter which needed to be tackled was the question of how both sides would negotiate with each other. The Turkish and Greek Cypriot representatives had a chance to talk about the direction of inter-communal talks in the UN Security Council meeting in New York in March 1968.

The Greeks did not demand any precondition to begin the dialogue, but they were reluctant to directly contact the Turkish Cypriot leadership and they wanted a mediator to conduct the negotiations. However, the Turks were in favour of the direct talks with the Greeks. ${ }^{70}$ It seemed that the reason for this Greek Cypriot request was to show that they did not recognise the Turkish Cypriot leadership and by demanding a mediator they tried to avoid giving any chance to the Turkish Cypriot Leadership to legitimise itself internationally. Nevertheless, the Greek concern was unnecessary because when the Turks announced the "Provisional Turkish Cypriot Administration"”on 28 December 1967, this Turkish move did not manage to get support from the international arena. In the end, the Greek Cypriots accepted to begin direct talks with the Turkish Cypriot Leadership. ${ }^{71}$

It should also be noted that other factors played important role in the initiation of the talks between the two communities. One of them was the meeting of the Greek and Turkish Foreign Ministers. According to a British evaluation, "the first move forward came in this secret meeting between Pipinelis and Çağlayangil in Switzerland. Pipinelis persuaded Çağlayangil to allow, and indeed encourage, talks between representatives of the two Communities, mainly on the constitutional question." 72

\footnotetext{
${ }^{69}$ TNA: FCO 9/73, "Cyprus", "British policy”, report of the Central Department of the Foreign Office, 20 March 1968.

${ }^{70}$ Milliyet, 20 March, 1968.

${ }^{71}$ Milliyet, 04 May, 1968.

72 TNA: FCO 51/47, Foreign And Commonwealth Affair‘s Research Department Memorandum, 4 December 1968.
} 
Meantime, the Turkish Cypriot leader Rauf Denktash, who lived in exile in Ankara, officially returned the island on 13 April $1968^{73}$ and took the Vice-President position in the Turkish Cypriot Administration. At a press conference, Denktash expressed the view that the Turkish Cypriots were ready to negotiate until they could find a mutual solution. ${ }^{74} \mathrm{He}$ also added that he believed that it was still possible for two communities on the island to live together in an independent Cypriot state. ${ }^{75}$ The UN Special Representative in Cyprus, the Mexican Bibiano Fernández Osorio y Tafall, helped the planning for the basis for the talks. The Turkish Cypriot chose Denktash as their representative and the Greeks designated Glafkos Clerides as their negotiator. ${ }^{76}$

It was a fact that although, at that time, Denktash seemed to be second man within the Turkish Cypriot Community after Vice-President Küçük, he was broadly regarded by the most Turkish Cypriots as a strong defender of their rights and the community's most active leader. ${ }^{77}$ He would also be an important actor through the inter-communal talks between the two communities.

The first formal contact between the both sides for a procedural discussion took place secretly in Nicosia on 23 May $1968 .^{78}$ It was a significant event in terms of shaping the course of the negotiations. Eventually, Clerides and Denktash met again in Beirut in early June. ${ }^{79}$ This was their first official contact publicly. ${ }^{80}$ The communities on the island were going to discuss for a solution for the problem. Until this time, two major powers, Greece and Turkey had tried to solve this issue, but the attempts were unsuccessful and sometimes brought more problems than they solved. In particular, Turkey had seemed to be ready to involve in the problem in any crisis on the island. Therefore, the question was that how would Turkey look at the intercommunal talks on the island?

From Turkey's angle, as stated before, the initiation of the direct the talks between the two communities did not bother Ankara. After the beginning of the negotiations, the Turkish Foreign Minister Çağlayangil stated that the Turkish government insists on solving problem by maintaining the necessary dialogue. ${ }^{81}$ Also, according to the Greek Cypriot Foreign Minister Kyprionou, in a meeting between the Turkish Foreign Minister Çağlayangil, it was confirmed that "the Turkish government was fully in favour of local talks", but Çağlayangil had also added that "they (local talks) were only a first stage towards settlement; at a second stage results must be put to the other governments concerned." 82 This showed that while giving support to the talks and encouraging them, Turkey did not want to fully disconnect from the Cyprus issue.

\footnotetext{
${ }^{73}$ Fırat, "Yunanistan'la İlişkiler”, p. 738., Melek Fırat, 1960-71 Arası Türk Dış Politikası ve Kıbrıs Sorunu, Siyasal Kitabevi, Ankara 1997, p. 227.

${ }_{74}$ Dışişleri Bakanlığı Belleteni, no: 43, April 1968, p. 23.

${ }^{75}$ Ibid.

${ }^{76}$ Bahcheli, Greek-Turkish Relations since 1955, p. 76.

${ }^{77}$ Bahcheli, op. cit., p. 75., Patrick, Political Geography, p. 157

${ }^{78}$ The Times, 27 May 1968.

79 "Kıbrıs Sorunun Tarihsel süreci”, Araştırma ve Etütler Merkezi, Turkish Ministry of Interior Affairs, http://www.arem.gov.tr/ortak_icerik/arem/Raporlar/degerlendirme/kibris_tarihsel_surec.pdf., Salahi R. Sonyel, Why did The Inter-Communal Talks on Cyprus (1968-71) Fail? Revelations in the light of British Official Documents released recently, Cyrep, Lefkoșa 2000, p. 3.

${ }^{80}$ Fikret Alasya, The republic of Cyprus and the events that have come to pass: The Aim and the Attitude of the Greeks, Ayyıldız Matbas1, Ankara 1969, p. 17, The Times, 3 June 1968.

${ }^{81}$ Milliyet, 19 July, 1968.

82 TNA: FCO 9/73, "Cyprus", "record of conversation between the Commonwealth Secretary and the Cyprus Foreign Minister held at Admiralty House', 28 June 1968.
} 


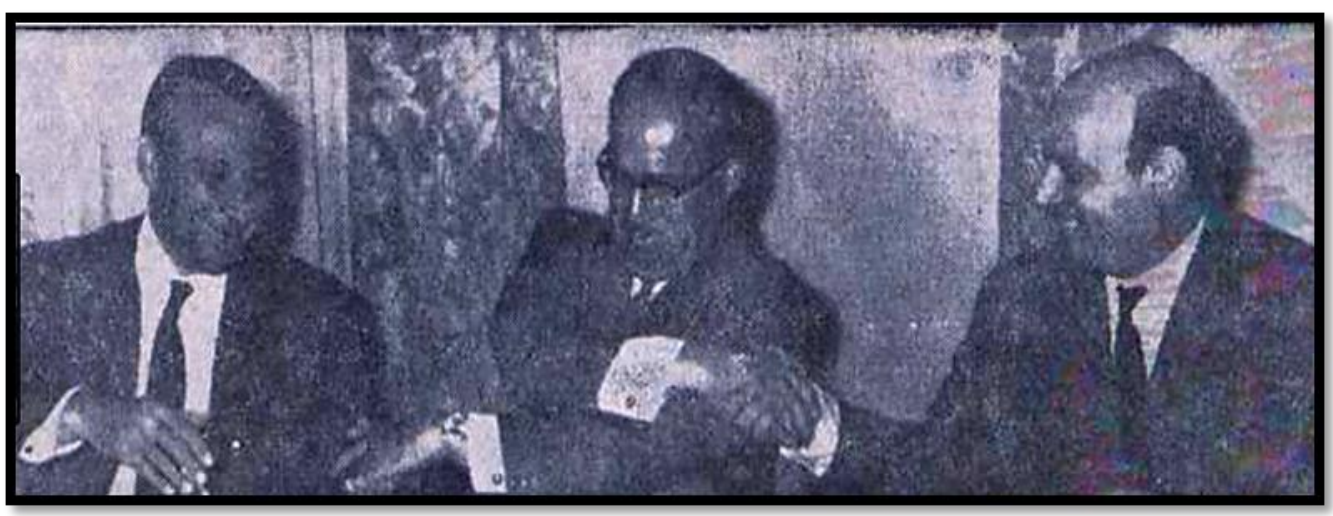

Glafcos Clerides; the UN Special Representative of the Secretary-General in Cyprus, Osorio y Tafall, and Rauf Denktash. Picture from the inter-communal meetings between Clerides and Denktash. Source: Milliyet, 27 June 1968.

There were different stages in the talks which lasted until 1971. The first phase of the talks began after the meeting of Clerides and Denktash. However both sides were unable to reach an agreement. The first stage of the negotiations was "mainly concerned with a rather untidy preliminary exchange of views and exploration of the attitudes of the two communities." 83 As stated by Polyviou, the Turkish side agreed with some of the issues for instance; they accepted "a reduction of the percentage of its participation in the civil service, the police and the legislature to that of its population ratio." ${ }^{84}$ Nevertheless, there were other issues which need to be tackled.

The second phase of the talks took place between 29 June 1968 and 25 July 1968 and the most significant topic of this section was the local authority issue. The Turkish Cypriot side mainly demanded that there would be separate a local authority council for the Greek and Turkish Cypriots. "Any coordination between the local Turkish authorities and the central government would be carried on by a Turkish Affairs Ministry, if created, or by the Turkish Vice-President. ${ }^{\prime 85}$ The Greek side did not give a positive reply to the Turkish Cypriot idea of the local authority and the second phase of the talks ended without reaching a conclusion.

According to the British evaluation of the Cyprus problem in 1968, it was reported that:

"The pace of the inter-communal talks is now snail-like, although both sides seem to intent on avoiding a breakdown in the near future. But the tension in the island has greatly relaxed over the past nine months, helped by Makarios' pacification measures, the meetings between the Cyprus and Turkish Foreign Ministers in the summer and the beginning of the inter-communal talks themselves in June. "86

\section{British and Turkish Disagreement on the Extension Period of UNFICYP (United Nations Peacekeeping Force in Cyprus) and the Soviet Danger}

The Cyprus issue did not concern just two communities on the island. It also had an international dimension. As a result of this fact, after the beginning of the talks, another discussion arose mainly between Turkey and Britain about the UNFICYP. The mandate of the

${ }^{83}$ Polyviou, Cyprus Conflict, p.64.

${ }^{84}$ Ibid., p. 65.

${ }^{85}$ Ibid., pp. 71-72.

${ }^{86}$ TNA: FCO 9/806, "United Nations Peacekeeping Force in Cyprus (UNFICYP) part A", "the United Nations Forces in Cyprus", letter from Secretary of State to the Prime Minister about 22 November 1968. 
United Nations Force had been extended for six months on 18 June 1968 and would expire on 16 December. Britain supported a renewal of the UNFICYP mandate on the island. According to the British view:

"The fact that talks are continuing between the Greek and Turkish Cypriots is encouraging. But they now seem to be running out of steam, and early agreement between the two sides is unlikely. UNFICYP has helped to maintain a favourable climate in Cyprus during the inter-communal talks, and whether the talks continue or break down, it will provide an essential stabilising factor. " 87

However, there was a disagreement between Turkey and Britain about the length of the extension of UNFICYP. When informing the Prime Minister about this issue, the British Foreign Minister argued that:

"In my view the mandate should be renewed for only three months this time. Experience has shown that with a longer extension the parties to the inter-communal talks are inclined to dawdle; and shorter renewal periods enable pressure to be kept up on the parties. He also said that 'the Americans and the Canadians have come round to the British view about this. " 88

The British evaluation of the renewal of the UN force in Cyprus seemed to be logical, but the purpose of keeping up the pressure between the Greek and Turkish sides was not the only reason for the British demand of a three month extension. The financial reason also appeared to play important role in the British request. Three month extension of the UNFICYP would cost $\$ 750,000$ for Britain ${ }^{89}$ and any longer extension would increase the amount. All these reasons led Britain to ask for a short period renewal of the United Nations Force on the island in the upcoming Security Council meeting in the early December 1968.

However, from Turkey's point of view a three month extension would not make a positive contribution to the situation in Cyprus. In a meeting with John Beith, the Permanent UnderSecretary of State at the British Foreign Office in London, the Turkish ambassador Haluk Bayülken underlined the point that:

"The Turkish government favoured a renewal of six months, not three. Bayülken explained to Beith that: their principal reason for this view that the inter-communal talks in Cyprus were developing into a long haul. There was no prospect that Mr. Denktash and Mr. Clerides would reach an agreement by next March (1969). Both of them favoured a renewal of the mandate for six months. It was important to show confidence in the two negotiators. A Security Council meeting in March (accepting three month extension in December meant that Security Council had to meet again in March for another extension decision) might have the opposite effect."

According to the observation of John Beith from the meeting, "the Turkish ambassador Bayülken understood that the UN Special Representative in Cyprus, Señor Osorio-Tafall, had now come round to the Turkish government's view." Beith also reported that "the ambassador, Bayülken, suggested that Security Council meeting with dealing with Cyprus should be kept few and far between because they offered an opportunity for the Soviet government to fish in

\footnotetext{
${ }^{87}$ Ibid.

${ }^{88}$ Ibid.

${ }^{89}$ Ibid.

${ }^{90}$ TNA: FCO 9/806, "speaking notes of the meeting between John Beith and the Turkish Ambassador, Haluk Bayülken”, 27 November 1968.
} 
the troubled waters of the Mediterranean and for Makarios to get up to new tricks." ${ }^{91}$ From the British side, there was no certain response to the Turkish view but Britain continued to be in favour of the three month renewal. In the end, by the suggestion of the Secretary of General of the United Nations six month extension of UNFICYP was accepted. ${ }^{92}$

Actually, the evaluation of Bayülken about the Soviet government was important because, in a near future, while the inter-communal talks were continuing, another crisis emerged after a meeting between the Soviet ambassador and Orhan Eralp, the Turkish delegate at the UN. In this meeting, "the Russians had informed that the Greek side was about the staging a coup d'état in Cyprus and that 600 saboteurs had been sent to Cyprus from Athens. The Soviet ambassador commented that this could not have been done without support from the Greek government. Eralp had replied that if a coup d'état took place Turkish reaction would be immediate." 93

Britain was not happy with the developments. According to the British view:

"The Russians have been active in stimulating, on the basis of "intelligence reports", rumours to the effect that the Greek government are planning a coup d'état in Cyprus, that they have been sending forces of saboteurs to the island and that their aim is to declare Enosis. From the subsequent conversations which we have had with the Turkish officials in Ankara, it would appear that the Turks realise the dangers of allowing these Russian stories and do not believe them all. "94

This event also showed that the Soviet government had continued to try to get a significant role in the Cyprus issue one more time.

\section{British Assessment on the Peace Talks between the Greek and Turkish Cypriots}

After two unsuccessful phases of the talks, the leaders of both communities were preparing to start the third round of inter-communal negotiations which lasted from 20 January 1969 to 17 August $1970 .{ }^{95}$ In this period disagreement continued between both sides. As a result of this, some rumours appeared that the talks had deadlocked, but Clerides and Denktash stated that talks were making progress. ${ }^{96}$ However, there were eight week intervals in the negotiation process ${ }^{97}$ and when both leaders resumed the talks in December 1969 "they agreed to shelve temporarily the local government issue and move on to other areas where compromises seemed more likely." 98

In his report to the Foreign Secretary, the British High Commissioner informed London about the negotiations between the both communities: "During the six months the intercommunal talks between Mr. Clerides and Mr. Denktash have continued. Despite the good will of both representatives and desire to reach agreement, it is now clear, after 12 months of discussion that no inter-communal settlement will emerge from their deliberation in the near

91 Ibid.

92 UN Security Council Resolution, 10 December 1968, Res. 261.

93 TNA: FCO 9/1161, “Attitude of Turkey towards Inter-Communal Dispute in Cyprus”, Information about the "conversation between Eralp of the Turkish MFA and the USSR Ambassador in Ankara", telegram no: 849, 19 March 1970.

94 TNA: FCO 9/1161, “Secretary of State's Lunch with the Turkish Ambassador” on 23 March 1971.

${ }^{95}$ Patrick, Political Geography, p. 172.

${ }^{96}$ The Times, 30 June 1969.

${ }^{97}$ Ibid. 2 December 1968.

${ }^{98}$ Patrick, op. cit., p. 173. 
future." ${ }^{99}$ The comment of the High Commissioner on the inter-communal negotiations seemed to be hopeless. However, he added that:

"Nevertheless, the talks have been partially successful to the extent that have served as a safety valve for the release of inter-communal tension; they have settled some minor but contentious points; they have shown that there are some areas of agreement, although these cannot be implemented in advance of an overall settlement; and they have helped to maintain contact and some degree of co-operation between the two communities.", 100

Meantime, the inter-communal talks were continuing between the two communities. The negotiators exchanged the proposals. "The judiciary was discussed from January 1970 to March 1970 and legislative problems dealt with between April and June." ${ }^{101}$ However, both sides could not manage to reach an agreement. Therefore, the third phase of the talks also duly broke down. ${ }^{102}$

The assessments on the process of the third stage of the talks were also giving a signal that the both negotiators would not be able to bring a solution for the problem. The report of UN Secretary General U Thant to the Security Council for the period June-December (1970) was a good example which described the situation on the island:

"The record of the past six months shows neither progress toward further normalisation nor a return to the tense and explosive situation which existed prior to the commencement of the inter-communal talks in June 1968. The situation now prevailing in Cyprus is one of 'negative stability'; quiet on the surface, but strained, abnormal and fraught with the serious danger inherent in the continuing close confrontation of well-armed military forces. With the passing time, this situation is threatening to become the way of life of all Cypriots, thus perpetuating the need for UNFICYP's presence in the island." 103

The report of the British High Commissioner, Peter E. Ramsbotham, in Nicosia also presented the situation of the negotiation in 1970 between the both sides:

"In the inter-communal talks, the most notable event was the preparation by $\mathrm{Mr}$ Clerides and Mr Denktash of a joint document listing their points of agreement and disagreement on the five major constitutional issues. (...) The two sides remain deadlocked between Turkish Cypriot demands for constitutional guarantees of their security, self-administration and "partnership" in the government of Republic, and Greek Cypriot insistence on a unitary State, constitutionally secure from the risk of partition. Toward the end of the year there was a faint glimmer of hope that the two sides were seriously reviewing their position and might at last be moving towards substantive negotiations. "104

Although the expectation for the solution of the problem through the negotiations was at a low level, the British High Commissioner in Nicosia again underlined that:

\footnotetext{
${ }^{99}$ TNA: DEFE 11/638, "Cyprus", "Cyprus: Future British Policy”, report from the British High Commissioner in Cyprus to the Secretary of State for Foreign and Commonwealth Affairs, 16 July 1969.

${ }^{100}$ Ibid.

${ }^{101}$ Patrick, op. cit., p. 173.

${ }^{102}$ Polyviou, Cyprus Conflict and Negotiation, p.87.

103 TNA: FCO 9/1358, “Cyprus annual review”, Cyprus Annual review for 1970’ report from "the British High Commissioner in Cyprus to the Secretary of State for Foreign and Commonwealth Affairs", 1 January 1971. ${ }^{104}$ Ibid.
} 
"The inter-communal talks are, nevertheless, an important factor in Cyprus. In 1970 they have proved valuable as a forum for discussing practical matters such as the return of the return of Turkish Cypriot displaced persons, providing aid to the Turkish Cypriot community, and economic co-operation between the two communities. (...) Both sides agreed that the talks should continue, and it is at least encouraging that both have turned their faces against the use of force as a way of solving their problem.",105

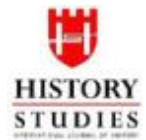

71

Volume 10 Issue 9 December 2018

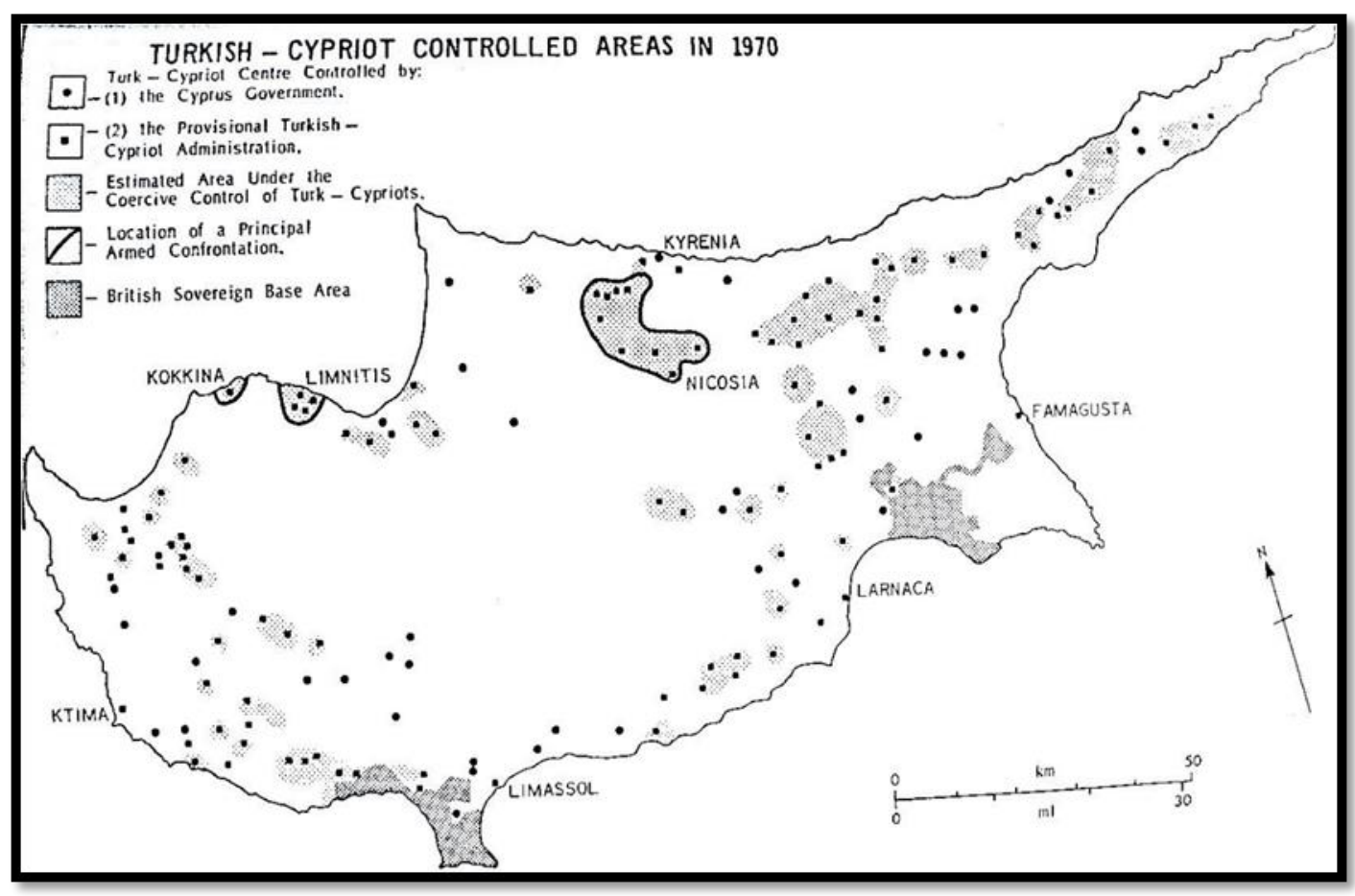

Turkish Cypriot-controlled areas in 1970. Source: Richard A. Patrick, Political Geography and the Cyprus Conflict 1963-1971, p. 464.

Another important area which needs to be analysed is the British policy in the negotiation process. In the early stage of the talks, the Americans and British decided not to involve in substance of talking points but instead encourage both parties to continue the dialogue. ${ }^{106}$ It was true that Britain avoided interfering in the talks between the communities. While meeting the Turkish ambassador to London, Bayülken, the British Permanent Under-Secretary of State, John Beith, explained that they "attached great importance to a successful outcome to the intercommunal talks, and will continue to give the encouragement." He also said they believe that "attempts to achieve full settlement of the constitutional problem can best proceed pari passu with attempts to improve the position on the ground. We do not think we should get involved in the detail of the talks, since we doubt whether this would be helpful." ${ }^{107}$ In his report the British High Commissioner, Ramsbotham, indicated the reasons behind their policy:

\footnotetext{
105 Ibid.

${ }^{106}$ Claude Nicolet, "Lack of Concern, Will and Power: British Policy towards Cyprus, 1961-1974”, (eds.), Britain in Cyprus: Colonialism and Post-Colonialism, 1878-2006, H. Faustmann \& N. Peristianis Mannheim und Möhnesee: Peleus, Studien zur Archaeologie und Geschichte Griechenlands und Zyperns, Band 19, Bibliopolis 2006, p. 501.

${ }^{107}$ TNA: FCO 9/806, "speaking notes of the meeting between John Beith, the British Permanent Under-Secretary of State, and the Turkish Ambassador, Haluk Bayülken", 27 November 1968.
} 
"The policy of standing back has served us well. Our interest in Cyprus, particularly our position as a Guarantor Power and our military interest in the Sovereign Base Areas, gives us influence but also make us peculiarly vulnerable should any initiative by us misfire. Our general interest in peace and stability is identical with that of our allies but our particular interest may differ. The risk for us of embarking once more on an active Cyprus policy, with the danger of alienating one or other communities and their mainland backers with whom we have relatively little influence, are substantial. $" 108$

However, the High Commissioner added that the situation in Cyprus was different by 1970. According to him, although, in the early stage of the talks, Britain preferred "standing back", this strategy seemed not to help in finding a solution to the problem. The intercommunal talks were proceeding slowly and there was danger of termination of the talks. As a result of this, the British High Commissioner on the island, Ramsbotham, wrote a report to the Foreign Secretary and set the scene for the British policy review:

\section{Is a change of policy of required?}

"External circumstances are favourable to a Cyprus solution, but differences between the communities within Cyprus probably preclude one.' Therefore, 'If policy is to be changed the attempt must be made to promote a new modus vivendi. This should not prejudice the important requirements of both sides under an eventual settlement and should attempt to reconcile the proposals each has made over normalisation. The High Commissioner suggests that the main elements might be devices for keeping the intercommunal talks going, by broadening the agenda introducing a third party to the negotiations; measures of demilitarisation; greater freedom of movement; and some sort of assurance against external attack. "109

Nevertheless, the argument of the High Commissioner did not manage to find support. The answer to the High Commissioner from the Foreign and Commonwealth Office was not positive. It was said that:

"We do not believe that promotion by outsiders of a modus vivendi or temporary settlement is a realistic proposition in the immediate future.(...) we should prefer to limit our actions to encouraging progress towards a settlement by the customary gentle pressures in general terms on the main parties to the dispute. We should do what we can to keep Greek and Turkish relations close and we should continue to emphasise the lack of any viable alternative to the inter-communal talks. But we should wish to avoid positive proposal. ",110

Although Britain was applying the "standing back" policy, it appeared that Britain was ready to be actively involved in the Cyprus problem when the separation of the island became a matter. As a good illustration of this argument, it can be shown that when the intercommunal talks seemed to fall short of meeting the expectation for the solution of the problem, some rumours started to rise on the island. According to this, the Turkish Cypriots, with the

\footnotetext{
108 TNA: FCO 9/1165, "Policy of United Kingdom towards Cyprus", "Cyprus Policy for 1970": report from the British High Commissioner in Cyprus to the Secretary of State for Foreign and Commonwealth Affairs, 4 March 1970.

109 Ibid.

110 TNA: FCO 9/1165, “Cyprus: Policy”, 10 April 1970.
} 
support of the Turkish government, were to declare a separate state in Cyprus. ${ }^{111}$ It was a serious issue. From the Britain's point of view, the Turks were unlikely to take such action. ${ }^{112}$ However, in case of any Turkish Cypriots declaration of a separate state, Britain indicated that they would show a reaction such a Turkish move and would be actively involved in the Cyprus question:

“(a) We could not accept the legality of such a unilateral partition. Under Article II of the Treaty of Guarantee, we undertook to guarantee the territorial unity of Cyprus.

(b) We could not accept the effective dismemberment of a member of the Commonwealth, against the wishes of the government of that country.

If the Turkish move presented with a fait accompli our scope for action would probably be limited. The minimum that we should do in the short term would be:

(a) To protest in the strongest terms to the Turkish government and urge them to revoke their decision.

(b) To take action to a similar end in NATO and with the UN Secretary General.

(c) To condemn the decision publicly and unequivocally and to restate our support for a unified Cyprus.",113

This British reaction indicated that Britain was still in favour of a solution which does not split the two communities on the island but unifying them under the umbrella of the one state. From this point of view, Britain was clearly against any attempts from the Turks to establish their own administration on the island. Meanwhile, the new developments in Cyprus were going to interrupt the peace negotiations between the Greek and Turkish Cypriots.

\section{Suspension of the Inter-Communal Talks in 1971 and the Establishment of "EOKA-B"}

The phase four of the negotiations between both communities' representatives started on 21 September 1970 and lasted until 20 September $1971 .{ }^{114}$ In this stage, first movement came from the Greek Cypriot side. They offered a "package deal" which was adjusting the Greek Cypriot position on some issues. ${ }^{115}$ According to this, mainly, it was accepted that the House of Representatives would comprise 60 Greek and 15 Turkish members and there would be a Turkish Vice-President. Also, there were some other arrangements paralleled to the Turkish Cypriots requests. ${ }^{116}$ After giving the new proposal, it was announced that there would be no further concessions. ${ }^{117}$ Although the Greek Cypriots "package deal" seemed to bring an offer which was more agreeable, the local authority issue appeared to continue as an important obstacle to the settlement because, in return for their offer, the Greek side demanded that the proposal of separate central local government authorities for the both communities on the island should be abandoned by the Turkish Cypriots. ${ }^{118}$ Turkey's approach towards the Greek offer was also significant, but meanwhile, Turkey had serious internal problems. There was a

\footnotetext{
111 TNA: FCO 9/1157, "Implications of possible double Enosis in Cyprus involving union of part of Cyprus with Greece and part with Turkey", "declaration of a separate Turkish Cypriot state", letter from FCO's Southern European Department, 10 September 1970.

${ }_{112}$ Ibid.

${ }^{113}$ Ibid.

${ }^{114}$ Patrick, Political Geography, p. 173.

${ }^{115}$ Nedjatigil, The Cyprus Conflict, p. 43, Polyviou, Cyprus Conflict, p. 78.

${ }^{116}$ Ibid., p.43, Ibid., p. 79.

${ }^{117}$ Patrick, op. cit., p. 173.

${ }^{118}$ Polyviou, Cyprus Conflict, p. 79
} 
political instability in the country. The Justice Party, which came to power with the general election in 1969, was in a difficult situation. Dissident voices against Prime Minister Süleyman Demirel within his own party caused him to resign. Also, the clash between extreme left-wing and right-wing groups was causing a chaotic environment on the streets. ${ }^{119}$ The Turkish Army saw the situation as an opportunity to intervene in politics and the commanders in the army issued a threatening memorandum ${ }^{120}$ on 12 March 1971 accused the government of being responsible for the condition of the country and stated that the army would take over the administration directly if the problems were not solved. As a result of this threat, the Prime Minister Demirel resigned and a new military-backed government was established.

The formation of the new government in Turkey was an important development and it was unclear how this situation would affect the course of the Cyprus problem. Actually, even before the military intervention, the Turkish government made its position clear to Britain. The Turkish ambassador to London gave the enclosed statement on 5 January 1971 which was explaining the Turkish demands for a solution of the inter-communal dispute in Cyprus. In general, the Turkish requirements were not different from the past Turkish statements. It was mainly advocating "granting local autonomy to the Turkish Cypriot community, in exchange for certain of their rights deriving from the 1960 Constitution." 121 This message seemed to be a signal that the Turkish side would not accept the Greek side "package deal". The Turkish Cypriots also appeared to find the Greek proposal insufficient because when the Turkish Cypriots leadership had a meeting the British Prime Minister in Nicosia on 7 January 1971 Denktash criticised Makarios by saying that "he was not in need of settlement: he had little or nothing to lose by waiting." 122 In this meeting the Turkish side also explained that the problem was that the Greek side wanted to give them a minority status by offering what amounted to minority rights to the Turkish Cypriots. According to Turkish opinion, this would enable the possibility of Enosis at some point in the future. The British Foreign Office report also indicated the expectations of Archbishop Makarios from the inter-communal talks:

"He sought to ensure Greek Cypriot authority is asserted throughout the island. The Turkish Cypriots, with only eighteen per cent of the population should be treated as an ethnic minority with special privileges but with no more than a proportionate voice in national affairs. ",123

The Turkish side did not answer the Greek offer immediately and it took a bit long. The new military-backed government's Prime Minister Nihat Erim had meetings with Rauf Denktash between 13 and 16 April 1971. In these meetings, it was said to Denktash that Turkey would continue to protect the rights of the Turkish Cypriot community on the island. It mentioned that the Turkish government would work to solve the economic problem of the Turkish Community which was living in a very difficult economic condition since the 1963 events. ${ }^{124}$

After the meeting the Turkish Prime Minister, Denktash replied to the Greek proposal on 27 April 1971. According to this, it was accepted that the Turkish Vice-President would no

\footnotetext{
${ }^{119}$ Wiener, Turkish Foreign Policy, p. 226.

${ }^{120}$ Kurtuluş Kayalı, Ordu ve Siyaset 27 Mayıs- 12 Mart, İletişim Yayınları, İstanbul 1994, p. 182.

${ }^{121}$ TNA: FCO 9/1367, "Attitude of Turkey towards the Inter-Communal Dispute in Cyprus", "Cyprus", 5 January 1971.

${ }^{122}$ TNA: FCO 9/1371, "Policy of the UK towards Cyprus Part A', 'the Prime Minister's meeting with Dr. Kutchuk (Küçük) in Nicosia", 7 January 1971.

${ }^{123}$ TNA: FCO 9/1371, “British Policy towards Cyprus”, FCO’s Southern European Department Report, Annex B: Demands of the Parties, 2 March 1971.

124 TNA: FCO 9/1372, "Policy of the UK towards Cyprus Part B", press release, 17 April 1971.
} 
longer have a power of veto, but the Turkish side demanded that "a local government district which would be autonomous, with such autonomy so written into a constitution and the boundaries of the autonomous districts would be drawn primarily according to communal consideration." ${ }^{\prime 25}$ By demanding local autonomy, the Turkish Cypriots thought that they could live in a more secure environment. During the fighting in the previous November many Turkish Cypriots lost their life. As a result of this, establishing their security appeared to be most important element for the Turkish Cypriot community. However, the Greek side did not agree with the Turkish Cypriot proposals. According to them, such a government structure would be "expensive, inefficient and guaranteed to irritate rather than soothe inter-communal feelings." 126 In addition, the Greek Cypriots leadership considered the Turkish Cypriot proposal as creating "a state within a state and the prelude to future partition." 127 Having radically different thoughts about the solution to the problem was making it more difficult to reach an agreement between the both sides.

The new military-backed Turkish government's approach towards inter-communal talks is a significant point to analyse. Although Turkey had internal problems, the Cyprus dispute was still an important agenda in the Turkish government programme. It was said that "Cyprus was a national cause over which no effort would be spared to attain success. The solution would also help to restore Turkish-Greek relations to their old friendliness." 128 It was a fact that the Cyprus problem was also affecting the relation between Greece and Turkey negatively. In a one statement, Turkish Prime Minister, Nihat Erim said that after the solution of the Cyprus dispute, a new period would start in the Greek-Turkish relations. ${ }^{129}$ Therefore, the aim of improving the friendship with its neighbouring country could be regarded as one of the motivating elements for the new Turkish government in finding a solution for the problem. Furthermore, there were other factors which would prompt Turkey to support reaching an agreement to the dispute. The report of the British Embassy in Ankara about the attitude of the Turkish government towards the inter-communal talks indicated that three elements would urge the Turkish government to take productive action in the Cyprus issue which were "Turkey's internal situation, their counting distrust of Makarios and their understandable impatience at the lack of progress in the inter-communal talks." ${ }^{130}$ Indeed, the long negotiation process was economically affecting the Turkish Cypriots in a negative way. The gaps between the both communities were becoming wider and an urgent solution to the problem seemed to be more needed by the Turkish community on the island.

After the Turkish Cypriot answer, the Greek Cypriot negotiator Clerides made a further proposal on 27 June 1971 suggesting some further arrangements. For example, he thought the Turkish Cypriots could form several areas of local government by grouping a number of Turkish villages together. ${ }^{131}$ However, the Greek side continued to be against the Turkish Cypriot request for separate central government authority for the both communities. ${ }^{132}$ As a result of this, once again, the Greek offer did not help towards a compromise with Turkish

\footnotetext{
${ }^{125}$ Patrick, Political Geography, p.174.

${ }^{126}$ Ibid. p. 174

${ }^{127}$ Bahcheli, Greek-Turkish Relations since 1955, p. 79.

${ }^{128}$ TNA: FCO 9/1367, "Turkish government Programme", unclassified telegram from the British Embassy in Ankara to FCO, no: 2552, 17 December 1971.

${ }^{129}$ Milliyet, 27 July 1971.

${ }^{130}$ TNA: FCO 9/1367, “Turkish government's attitude to Cyprus”, confidential letter from the British Ambassador in Ankara, Sir Roderick Sarell to FCO's Southern European Department, 18 May 1971.

${ }^{131}$ Polyviou, Cyprus Conflict, p. 84.

${ }^{132}$ Ibid, p. 84.
} 
Cypriots or to meet their expectations. ${ }^{133}$ The Turkish Cypriot leader Rauf Denktash stated that there was no basis for negotiations. According to him, there were vital differences on basic issues which had made further talks pointless but he also said that "the Turkish side would not take initiative in breaking the inter-communal talks off."134 Ankara was not also happy with the course of the negotiations. The Turkish Foreign Minister Osman Olcay announced that "progress in the Cyprus talks had left him with little hope that they would yield positive results." 135 As a natural consequence of the negative atmosphere on the island, by August 1971, "both communities publicly recognised that the talks were deadlocked.",136

This situation raised concerns about the future Cyprus problem. Britain was trying to follow the events closely. In a report which was given to Foreign Secretary Sir Alec Douglas Home by the British High Commissioner to Cyprus, Robert Edmonds, on 31 August, 1971, the possible dangerous results of breaking off the inter-communal talks were pointed out. According to this report, if the negotiations between the two communities halted, a crisis could emerge on the island. In particular, the report expressed the view that the newly established Turkish government could use the military card again to increase its popularity among the public in Turkey. Also, as a significant analysis in this report it was said that "if the Turkish General Staff learnt anything from the November crisis in 1967, it must be that they should "invade" Cyprus while the going is good, without waiting for the international diplomatic machine to get into gear." ${ }^{" 137}$ By making this assessment, Britain predicted the way in which Turkey would use in any major crisis on the island. This analysis might not be correct for the 1971, but is better suited to the Turkish military operation in Cyprus in 1974. The last negotiation attempt in 1971 was on 20 September. Both sides had a meeting but it ended with failure. ${ }^{138}$ Therefore, the talks stalled. ${ }^{139}$

It is important to analyse the points which led to a halt in the inter-communal talks without producing a successful outcome. Firstly, having different expectations through the negotiation process was an important factor in the failure of the talks. Although having the regional autonomy in their enclaves was a vital target for the Turkish Cypriots, preserving the total control of the government mechanism and a unitary state were two essential criteria for the Greek Cypriots. Another important reason behind the deadlock in the negotiation process was the lack of trust between the two communities. They were generally suspicious of each other's requests.

An event that occurred on the island is an example which highlights the situation between two sides. British troops from the Akrotiri base repaired a road which was between two Turkish Cypriots villages. The road was also being used by the British soldiers and the bad condition of the road was damaging their vehicles. This was the main reason to repair the road. However, the Greek Cypriot authorities considered the action as a favour to the Turkish

\footnotetext{
${ }^{133}$ Nedjatigil, The Cyprus Conflict, p. 43.

${ }^{134}$ The Times, 21 July 1971.

${ }^{135}$ The Times, 23 July 1971.

${ }^{136}$ Patrick, Political Geography, p. 177.

${ }^{137}$ TNA: FCO 9/1372, “The British Stake in the Cyprus game: New rules, new policy?”, report from the British High Commissioner to Cyprus, Robert Edmonds, to Secretary of State Sir Alec Douglas Home, 31 August 1971.

${ }_{138}$ Patrick, op. cit., p. 177.

${ }^{139}$ Necati M. The Cyprus Dispute and the Birth of the Turkish Republic of Northern Cyprus, (2nd ed.), K. Rustem \& Brothers, Nicosia 1984, p. 25.
} 
Cypriots and complained to London about the action of the British troops on the island. ${ }^{140}$ While such a small incident could be interpreted as a problem, it was difficult to reach agreement on the major issues. Later, Clerides would regret that no solution emerged in his dialogue with Denktash. In his statement on the inter-communal talks, Clerides said that "unfortunately, we did not grasp the opportunity which was here from 1968-1970."141

Apart from the deadlock in the talks, there was another important development on the island in terms of the Cyprus Problem. In September 1971, it was understood that the Greek General George Grivas, who had been living in exile in Greece after the crisis in November $1967,{ }^{142}$ had escaped from Athens and secretly entered Cyprus. ${ }^{143}$ He set up and started to lead a so-called terrorist organisation EOKA-B to continue the struggle for unification with Greece. ${ }^{144}$ According to the British High Commissioner's assessment Grivas entered Cyprus earlier and he was in hiding. ${ }^{145}$ Grivas' return date to the island was on 31 August $1971 .{ }^{146}$ This was a serious situation that affected the both communities in Cyprus. Grivas' presence on the island split the Greek Cypriot community. ${ }^{147}$ He claimed that Makarios was betraying the Greek national cause Enosis. He also stated that the Greek Cypriot leadership under Makarios was useless for the Greek community and the main reason for his return was to complete the age-long goal of the Greek community to unite Cyprus with Greece. ${ }^{148}$ According to British High Commissioner in Nicosia, although Makarios continued to be the most powerful leader among the Greek Cypriots, the reappearance of Grivas "has shaken the allegiance of many Greek Cypriots to the Archbishop." 149 The High Commissioner also emphasized the fact that Grivas had the possibility of getting 40 percent of the vote in a Presidential election "if he were politically skilful enough to dodge the question how Enosis could be achieved without leading to partition." ${ }^{150}$ The effect of Grivas' presence among the Cyprus National Guards, "whose commander and most of its officers were mainland Greeks who took their orders from Athens and had no love for the Cyprus government," violence on the island and this situation was causing disturbance in Cyprus. According to supporters of the Grivas, he was planning a coup to take over the control in Cyprus. ${ }^{152}$ Moreover, illegal underground groups were being formed in Cyprus and they were taking an oath of loyalty to Grivas. ${ }^{153}$

Greek Cypriot reservist officers, who served formerly in the National Guard, had also taken sides with Grivas and they sent a message to Makarios that denounced his policy of

\footnotetext{
${ }^{140}$ TNA: FCO 9/1373, "Policy of the UK towards Cyprus Part B", restricted telegram from FCO to the British high Commission in Nicosia, no: 688, 26 October 1971.

${ }^{141}$ Glafkos Clerides, Cyprus: My Deposition, Vol. 2, Alithia Publishing, Nicosia 1989, p. 382.

${ }^{142}$ Denktash, The Cyprus Triangle, p. 60.

${ }^{143}$ Clerides, op. cit., Vol. 3, p. 15.

${ }^{144}$ Uslu, The Cyprus Question, p. 108., Monteagle Stearns, Entangled Allies: US Policy Toward Greece, Turkey, and Cyprus, Council on Foreign Relations Press, New York 1992, p. 115.

${ }^{145}$ TNA: FCO 9/ 1494, '”Annual Review of Cyprus for 1971', report from 'British High Commission at Nicosia to the Secretary of State for Foreign and Commonwealth Affairs", 1 January 1971.

${ }^{146}$ Andreas Constandinos, America, Britain and the Cyprus Crisis of 1974: Calculated Conspiracy or Foreign Policy Failure?, Author House, Central Milton Keynes 2009, p. 83.

${ }^{147}$ TNA: FCO 9/ 1494, op. cit.

${ }^{148}$ Denktash, The Cyprus Triangle, pp. 60-61.

${ }^{149}$ TNA: FCO 9/1495, "General Grivas and the Cyprus Problem", "Makarios versus Grivas", report from British High Commissioner at Nicosia to the Secretary of State for Foreign and Commonwealth Affairs, 6 December 1971.

${ }^{150}$ Ibid.

${ }^{151}$ Ibid.

${ }^{152}$ The Times, 11 September 1971.

${ }^{153}$ Ibid., 26 October 1971.
} 
reconciliation with the Turkish Cypriots in a unitary political solution by insisting on Enosis. ${ }^{154}$ Finally, there was the demand of "new noble national struggle" to unite Cyprus for Greece by a group of sixty-two Greek Cypriots calling itself the "Coordination Committee for the Enosis Struggle" 155 which increased the concern over the future of the island. In particular, the concern of the Turkish community was at a high level. In his meeting with Foreign and Commonwealth Secretary, Sir Alec Douglas-Home, the Turkish Foreign Minister, Osman Olcay, expressed the view that "the situation was not at all encouraging." 156 According to the British Foreign Secretary, "Turkey's main concern was that the Turkish community on the island should not lose hope." 157 For this purpose, Turkey was closely following the developments. From this point of view, it is important to look at the Turkish opinion about the struggle between Makarios and Grivas. It can be said that the Turks accepted that Makarios had a reasonable approach towards the Cyprus dispute compared to Grivas because it appeared that while "Makarios insisted on caution and a low-geared approach, Grivas wanted an immediate military campaign." 158 However, the Turkish side also believed that the both the Greek leaders had accepted Enosis as their common goal and their only difference was in the manner of achieving it. ${ }^{159}$

The return of Grivas to the island was not also welcomed by Britain. The struggle the between two communities could damage to Britain's own interest on the island. In the British cabinet, this issue was discussed and it was stated that: "A deterioration in the situation might have serious implications for our installations there, both inside and outside the Sovereign Base Areas, which were of very considerable importance to us." 160 Apart from this from this concern, when making the assessment of the year of 1971 for Cyprus, Britain examined the development on the island from two different perspectives. Firstly, from the standpoints of Anglo-Cypriot relations, the British High Commissioner in Nicosia stated that 1971 was a good year. Economic relations increased and Britain managed to remain the biggest trading partner of Cyprus. Secondly, from the angle of the Cyprus dispute, the High Commissioner said that it "was an unhappy year." ${ }^{161}$ It was true that the suspension of inter-communal talks without making any remarkable contribution to the Cyprus dispute and the return of the Greek General Grivas to the island increased the British concern. It was accepted that the Cyprus problem was at a critical juncture and it was also stated: "there is a real risk that the period of negative stability, which has lasted since 1968, maybe coming to an end." ${ }^{\prime 162}$ As mentioned before, a possible Turkish military operation on the island was a significant factor behind the British concern. According to British assessment, the new Turkish government which had come to power in Ankara was impatient with the stalemate in the talks ${ }^{163}$ and this could lead Turkey to use the military option which would be an unwanted development for Britain. In this context, the British government supported the continuation of the peace negotiations between the Greeks and Turks. Otherwise, a Turkish military operation in Cyprus could tense the relation between Ankara and London.

\footnotetext{
${ }^{154}$ Ibid, 30 October 1971.

${ }^{155}$ The Times, 22 November 1971.

${ }^{156}$ TNA: FCO 9/1367, "Record of conversation between the Foreign and Commonwealth Secretary and the Turkish Foreign Minister in the Waldorf Towers Hotel in New York", 28 September 1971.

${ }^{157}$ Ibid.

${ }^{158}$ Denktash, The Cyprus Triangle, p. 61.

${ }^{159}$ Ibid., p. 61.

${ }^{160}$ TNA: CAB 128/49, 'Post War Conclusion', CM (71), 52nd conclusion, 28 October 1971, p.3.

${ }^{161}$ TNA: FCO 9/ 1494, Cyprus: Annual Review for 1971, summary, registry no: 16, 10 January 1971.

162 TNA: FCO 9/1373, "the British Stake in Cyprus", secret letter from FCO to the British High Commission in Nicosia, 7 October 1971.

${ }^{163}$ Ibid.
} 


\section{Conclusion}

The British response to the establishment of the new Turkish administration on the island showed that there were major differences in the respective approaches towards the Cyprus issue by 1968. Although the Turks tried to explain that their aim at forming a separate administration of the island was to protect the Turkish Cypriots on the island, Britain regarded the Turkish move as an unfortunate development. ${ }^{164}$ This British attitude had a negative effect on Anglo-Turkish relations. Ankara started to understand more clearly that British support for Turkish arguments on the Cyprus issue was not forthcoming. Actually, it would be very problematic for Britain to formally recognise the new Turkish administration on the island because this would adversely impact upon its relations with Greece and the Greek Cypriot government, which showed a strong aversion to the new Turkish administration. Furthermore, the UN criticism of the Turkish action showed that recognising the new Turkish administration would put Britain in a difficult position in the international arena.

Another issue by 1968 was that the British Government seemed to consider the hardening Turkish position as an obstacle to the solution of the Cyprus dispute. Therefore, the British policy makers tried to "encourage the Turkish government to allow the Turkish Cypriots to make a positive response to any conciliatory moves made by the Greek Cypriots." ${ }^{165}$ When inter-communal talks were started between the Greek and Turkish Cypriots encouraged by intensive efforts by the United Nations, British officials announced their support for the continuation of the negotiation process between the two sides. However, the representatives of the two communities found it difficult to compromise with each other. Britain avoided publicly criticising any attitude by the involved parties in the talks and applied a policy of "standing back" in order not to worsen its relations with Athens and Ankara. On the other hand, the Foreign Office documents showed that in the event of a declaration of a separate state on the island by the Turkish Cypriots, Britain was ready "to protest in the strongest terms to the Turkish government and urge them to revoke their decision." ${ }^{166}$ Even though, such a statement would have a negative effect on the Anglo-Turkish relations. In the meantime, the suspension of the inter-communal talks in 1971, due to the difference of opinions of the Greek and Turkish sides and establishment of the terrorist organisation EOKA-B worsened the general situation on the island. Ankara showed a strong reaction to the activities of Greek General Grivas on the island. In this sense, the British and Turkish policy were in parallel because Grivas' return to the island was not also welcomed by Britain either.

\footnotetext{
164 TNA: FCO 51/47, Foreign And Commonwealth Affair's Research Department Memorandum, 4 December 1968 165 TNA: FCO 9/73, "Cyprus", "British policy”, report of the Central Department of the Foreign Office, 20 March 1968.

166 TNA: FCO 9/1157, "Implications of possible double Enosis in Cyprus involving union of part of Cyprus with Greece and part with Turkey”, "declaration of a separate Turkish Cypriot state”, letter from FCO's Southern European Department, 10 September 1970.
} 


\section{Bibliography}

\section{Archival Sources}

\section{The National Archives, Kew, United Kingdom:}

Foreign Office, Central Department and Foreign and Commonwealth Office (FCO):

The National Archives (TNA): TNA: FCO 9/72, 'Cyprus', telegram from the British Ambassador to Turkey, Sir. Roger Allen, to Foreign Office, 18 October 1967.

TNA: FCO 9/73, "Cyprus", "British policy", report of the Central Department of Foreign Office, 20 March 1968.

TNA: FCO 9/73, "Cyprus", record of conversation between the Commonwealth Secretary and the Cyprus Foreign Minister held at Admiralty House, 28 June 1968.

TNA: FCO 9/85, "United Nations Peacekeeping Force in Cyprus (UNFICYP): finances and support", "Cyprus", letter from the British High Commission in Cyprus, 2 February 1968.

TNA: FCO 9/806, "United Nations Peacekeeping Force in Cyprus (UNFICYP) part A", "the United Nations Forces in Cyprus", letter from Secretary of State to the Prime Minister about 22 November 1968.

TNA: FCO 9/806, "speaking notes of the meeting between John Beith and the Turkish Ambassador, Haluk Bayülken”, 27 November 1968.

TNA: FCO 9/1157, "Implications of possible double Enosis in Cyprus involving union of part of Cyprus with Greece and part with Turkey", "declaration of a separate Turkish Cypriot state", letter from FCO's Southern European Department, 10 September 1970.

TNA: FCO 9/1161, "Attitude of Turkey towards Inter-Communal Dispute in Cyprus", Information about the "conversation between Eralp of the Turkish MFA and the USSR Ambassador in Ankara", telegram no: 849, 19 March 1970.

TNA: FCO 9/1161, "Secretary of State's Lunch with the Turkish Ambassador" on 23 March 1971.

TNA: FCO 9/1165, "Policy of United Kingdom towards Cyprus", "Cyprus Policy for 1970": report from the British High Commissioner in Cyprus to the Secretary of State for Foreign and Commonwealth Affairs, 4 March 1970.

TNA: FCO 9/1358, “Cyprus annual review”, Cyprus Annual review for 1970’ report from "the British High Commissioner in Cyprus to the Secretary of State for Foreign and Commonwealth Affairs", 1 January 1971.

TNA: FCO 9/1367, "Turkish government Programme", unclassified telegram from the British Embassy in Ankara to FCO, no: 2552, 17 December 1971.

TNA: FCO 9/1367, "Turkish government's attitude to Cyprus", confidential letter from the British Ambassador in Ankara, Sir Roderick Sarell to FCO's Southern European Department, 18 May 1971.

TNA: FCO 9/1367, "Record of conversation between the Foreign and Commonwealth Secretary and the Turkish Foreign Minister in the Waldorf Towers Hotel in New York", 28 September 1971. 
TNA: FCO 9/1371, "Policy of the UK towards Cyprus Part A', 'the Prime Minister's meeting with Dr. Kutchuk (Küçük) in Nicosia”, 7 January 1971.

TNA: FCO 9/1371, "British Policy towards Cyprus", FCO's Southern European Department Report, Annex B: Demands of the Parties, 2 March 1971.

TNA: FCO 9/1372, "Policy of the UK towards Cyprus Part B", press release, 17 April 1971.

TNA: FCO 9/1372, “The British Stake in the Cyprus game: New rules, new policy?", report from the British High Commissioner to Cyprus, Robert Edmonds, to Secretary of State Sir Alec Douglas Home, 31 August 1971.

TNA: FCO 9/1373, "Policy of the UK towards Cyprus Part B", restricted telegram from FCO to the British high Commission in Nicosia, no: 688, 26 October 1971.

TNA: FCO 9/1373, "the British Stake in Cyprus", secret letter from FCO to the British High Commission in Nicosia, 7 October 1971.

TNA: FCO 9/1494, “Annual Review of Cyprus for 1971”, report from 'British High Commission at Nicosia to the Secretary of State for Foreign and Commonwealth Affairs", 1 January 1971.

TNA: FCO 9/1495, "General Grivas and the Cyprus Problem", "Makarios versus Grivas", report from British High Commissioner at Nicosia to the Secretary of State for Foreign and Commonwealth Affairs, 6 December 1971.

TNA: FCO 51/47, Foreign And Commonwealth Affair's Research Department Memorandum, 4 December 1968.

\section{Cabinet Papers (CAB)}

TNA: CAB 128/43, "Post War Conclusion”, CC (67), 68th conclusion, 18 January 1968.

TNA: CAB 128/49, "Post War Conclusion”, CM (71), 52nd conclusion, 28 October 1971.

\section{Records of the British Minister of Defence (DEFE)}

TNA: DEFE 11/638, "Cyprus", "Cyprus: Future British Policy”, report from the British High Commissioner in Cyprus to the Secretary of State for Foreign and Commonwealth Affairs, 16 July 1969.

\section{Official Turkish Primary Documents:}

Dışişleri Bakanlığı Belleteni (The Bulletin of the Foreign Ministry), Ankara: Ministry of Foreign Affairs, 1967-1968.

\section{United Nations:}

UN Security Council Resolution, 10 December 1968, Res. 261.

\section{Books, Articles and Newspapers:}

"Kıbrıs Sorunun Tarihsel süreci”, Araştırma ve Etütler Merkezi, Turkish Ministry of Interior Affairs, http://www.arem.gov.tr/ortak_icerik/arem/Raporlar/degerlendirme/kibris_tarihsel _surec.pdf

ALASYA, Fikret, The Republic of Cyprus and the events that have come to pass: The Aim and the Attitude of the Greeks, Ayyıldı Matbas1, Ankara 1969. 
BABAOĞLU, Resul, “Türkiye'nin Kıbrıs Politikasının Evriminde Bir Dönüm Noktası: Londra Konferans1 (29 Ağustos-6 Eylül 1955)", Çă̆daş Türkiye Tarihi Araştırmaları Dergisi, Cilt: 18, Say1:36, Bahar-2018, p. 323-347.

BAHCHELI, Tozun, Greek-Turkish Relations since 1955, Westview Press, London 1990.

BÖLÜKBAŞI, Süha, "The Cyprus Dispute and the United Nations: Peaceful NonSettlement between 1954 and 1996", International Journal of Middle East Studies, Vol. 30, No. 3, August, 1998, p. 411-433.

CARVER, Michael M., The Gordian Knot: American And British Policy Concerning The Cyprus Issue: 1952-1974, (M.A. Thesis), Bowling Green State University 2006.

CLERIDES, Glafkos. Cyprus: My Deposition, Volumes 1 \& 2, Alithia Publishing, Nicosia 1989.

CONSTANDINOS, Andreas. America, Britain and the Cyprus Crisis of 1974: Calculated Conspiracy or Foreign Policy Failure?, Author House, Central Milton Keynes 2009.

COULOUMBIS, Theodore A., The United States, Greece and Turkey: The Troubled Triangle, Praeger, New York 1983.

DENKTASH, Rauf, The Cyprus Triangle, K. Rustem \& Bro, Nicosia 1982.

ERTEKÜN, Necati M. The Cyprus Dispute and the Birth of the Turkish Republic of Northern Cyprus, (2nd ed.), K. Rustem \& Brothers, Nicosia 1984.

EVRIVIADES, Marios L., "Greek Policy and Cyprus: An Interpretation", Journal of the Hellenic Diaspora, Vol. 14, No. 3-4, Fall 1987, p. 25-48.

FIRAT, Melek, "Yunanistan'la İlişkiler", Türk Dış Politikası Kurtuluş Savaşından Bugüne Olgular, Belgeler, Yorumlar 1919-1980, Ed. Baskın Oran, C. I, İletişim Yayınlar1, İstanbul, 2010.

FIRAT, Melek, 1960-71 Arası Türk Dış Politikası ve Kıbrıs Sorunu, Siyasal Kitabevi, Ankara 1997.

GÖKTEPE, Cihat, “The Cyprus Crisis of 1967 and its Effects on Turkey's Foreign Relations", Middle Eastern Studies, 41: 3, 2005, p. 431- 444.

GÜLER, Yavuz, "Kuzey Kıbrıs Türk Cumhuriyeti'nin Kuruluşuna kadar Kıbrıs Meselesi”, G.Ü. Kırşehir Eğitim Fakültesi Dergisi, Vol. 5, No. 1, 2004, p. 101112.

HART, Parker T., Two NATO Allies at the Threshold of War: Cyprus, a Firsthand Account of Crisis Management, 1965-1968, Duke University Press, London 1990.

KAYALI, Kurtuluş, Ordu ve Siyaset 27 Mayıs- 12 Mart, İletişim Yayınları, İstanbul 1994.

Milliyet, 30 December, 1967.

Milliyet, 31 December, 1967.

Milliyet, 20 March, 1968.

Milliyet, 04 May, 1968.

Milliyet, 19 July, 1968. 
Milliyet, 27 July 1971.

NEDJATIGiL, Zaim M., The Cyprus Conflict A Lawyer's View, Tezel, 2nd edn, Nicosia 1982.

NICOLET, Claude, "Lack of Concern, Will and Power: British Policy towards Cyprus, 1961-1974" in H. Faustmann \& N. Peristianis (eds.), Britain in Cyprus: Colonialism and Post-Colonialism, 1878-2006, Mannheim und Möhnesee: Peleus, Studien zur Archaeologie und Geschichte Griechenlands und Zyperns, Band 19, Bibliopolis 2006, p. 491-509.

OLGUN, Aydın, Dünden Bugüne Kıbrıs Sorunu, Kastaş Yayınları, İstanbul 1999.

PATRICK, Richard A., Political Geography and the Cyprus Conflict 1963-1971, Department of Geography, Faculty of Environmental Studies, University of Waterloo, Canada 1976.

POLYVIOU, Polyvios G., Cyprus in Search of a Constitution, Nicolaou, Nicosia 1976.

SONYEL, Salahi R., Why did The Inter-Communal Talks on Cyprus (1968-71) Fail? Revelations in the light of British Official Documents released recently, Cyrep, Lefkoşa 2000.

STEARNS, Monteagle, Entangled Allies: US Policy Toward Greece, Turkey, and Cyprus, Council on Foreign Relations Press, New York 1992.

TAMKOÇ, Metin, The Turkish Cypriot State: The Embodiment of the Right of Selfdetermination, K. Rustem \& Brother, London 1988.

The Times, 30 December 1967.

The Times, 5 January 1968.

The Times, 22 January 1968.

The Times, 27 May 1968.

The Times, 3 June 1968.

The Times, 30 June 1969.

The Times, 21 July 1971.

The Times, 23 July 1971.

The Times, 11 September 1971.

The Times, 26 October 1971.

The Times, 30 October 1971.

The Times, 22 November 1971.

USLU, Nasuh, The Cyprus Question as an Issue of Turkish Foreign Policy and TurkishAmerican Relations 1959-2003, Nova Publishers, New York 2003.

Vatan, 29 December 1967.

WIENER, Sharon Anderholm, Turkish Foreign Policy Decision-Making on the Cyprus Issue: A Comparative Analysis of Three Crises, (Ph.D. Thesis), Duke University 1980. 
YAVUZALP, Ercüment, Kıbrıs Yangınında Büyükelçilik, Bilgi Yayınevi, Ankara 1993. 